\title{
Perbedaan Hasil Pengukuran Horizontal pada Tulang Mandibula dengan Radiograf Panoramik
}

\author{
Munakhir Mudjosemedi, Rini Widyaningrum, dan Rellyca Sola Gracea
}

Bagian Radiologi Dentomaksilofasial, Fakultas Kedokteran Gigi, Universitas Gadjah Mada, Yogyakarta, Indonesia JI Denta No. 1 Sekip Utara, Yogyakarta, Indonesia; e-mail: rinihapsara@ugm.ac.id

\begin{abstract}
ABSTRAK
Radiograf panoramik mencitrakan gigi-geligi rahang bawah dan atas beserta seluruh jaringan pendukungnya dalam sebuah citra tunggal, proses pemeriksaannya murah, cepat, dan mudah, serta paparan radiasi yang diterima oleh pasien relatif rendah. Di samping memiliki sejumlah keunggulan tersebut, radiograf panoramik juga memiliki kelemahan karena gambaran yang dihasilkan pada teknik radiografi ini mengalami distorsi geometris, sehingga hasil pencitraan pada radiografi panoramik cenderung tidak sesuai dengan ukuran struktur anatomi yang sesungguhnya pada pasien. Penelitian ini bertujuan untuk mengetahui perbedaan hasil pengukuran horizontal pada preparat mandibula dibandingkan dengan pengukuran horizontal pada citra radiograf panoramik, serta untuk mengetahui seberapa besar distorsi pengukuran horizontal pada radiograf panoramik. Sampel penelitian berupa 56 buah preparat mandibula yang masing-masing diberi 23 buah metal marker. Radiograf panoramik diambil dari masing-masing sampel. Pengukuran horizontal pada sampel menggunakan sliding caliper digital, sedangkan pengukuran horizontal pada radiograf panoramik menggunakan komputer. Hasil penelitian menunjukkan bahwa terdapat perbedaan rerata yang bermakna $(p<0,05)$ antara hasil pengukuran pada radiograf panoramik dibandingkan dengan hasil pengukuran pada preparat mandibula, kecuali pada hasil pengukuran horizontal regio gigi geligi posterior dan regio median line hingga posterior korpus mandibula. Hasil penelitian ini menunjukkan bahwa pada penempatan posisi kepala pasien yang memenuhi standar akan dihasilkan radiograf panoramik dengan distorsi geometris berupa penyempitan dimensi horizontal pada regio anterior mandibula. Pengukuran horizontal pada radiograf panoramik memiliki akurasi yang baik jika dilakukan pada regio posterior, namun cenderung tidak akurat jika dilakukan secara memanjang melintasi median line.
\end{abstract}

Maj Ked Gi Ind. Juni 2015; 1(1): hal 78-85

Kata kunci: preparat mandibula, radiograf panoramik, pengukuran horizontal

\begin{abstract}
Differences of Horizontal Measurement on Dry Mandibles and Panoramic Radiographs. Panoramic radiograph produces one single image of both maxillary and mandibular dental arches and their supporting structures. This technique is cheap, fast and easy, with relatively low radiation exposure received by patients. However, the panoramic radiograph also has some disadvantages related to its geometric distortion. The images of patient's anatomical structures on panoramic radiograph are not equal with their actual dimension. The aim of this study is to determine the distortion of panoramic radiograph, by comparing the horizontal measurements on panoramic radiographs with those on the real object, which was the dry mandibles. The samples of this study were 56 dry mandibles with 23 metal markers on each of them. Panoramic radiograph was taken from each sample. Horizontal measurements on dry mandibles were done using digital sliding caliper, while horizontal measurements on panoramic radiograph were done using computer. The result of this study shows that there were significant differences $(p<0.05)$ between horizontal measurements on panoramic radiographs compared with the measurements on dry mandibles, except in posterior dental arch and median line up toposterior region of mandible corpus. The results of this study indicate that panoramic radiograph taken on standardized patient's head positioning procedure would produce geometric distortion that tends to be narrow on mandibular anterior region. The horizontal measurements of panoramic radiographs show good accuracy in posterior region, but tend to be inaccurate if done extended across the midline.

Maj Ked Gi Ind. Juni 2015; 1(1): hal 78-85
\end{abstract}

Keywords: dry mandible, panoramic radiograph, horizontal measurement

\section{PENDAHULUAN}

Pemeriksaan radiografi untuk menunjang perawatan pasien di bidang medis berkembang pesat sejak penemuan sinar X pada tahun 1895. Radiograf dental atau rontgen gigi pertama kali diambil pada tahun 1896, dan sejak saat itu radiologi menjadi salah satu komponen integral dalam pemeriksaan kedokteran gigi. ${ }^{1,2}$ Radiograf dental merupakan sarana pemeriksaan penunjang yang paling banyak dipergunakan dalam praktek dokter gigi, dan peralatan radiografi dental telah banyak tersedia di pusat layanan kesehatan di 
berbagai daerah di Indonesia. ${ }^{3}$ Kebutuhan akan pencitraan untuk menunjang pemeriksaan pada praktek dokter gigi mendorong berkembangnya teknologi radiografi kedokteran gigi. Film yang sejak awal perkembangan radiografi telah dipergunakan sebagai media pencitraan, saat ini perannya mulai digantikan oleh tayangan monitor dan media lain semisal kertas, sebagai manifestasi dari perkembangan teknologi terbaru di bidang radiografi, yaitu sistem radiografi digital. ${ }^{1,4}$

Kebutuhan akan teknologi pencitraan yang lebih presisi dan akurat menjadikan pemeriksaan radiografi tidak hanya terbatas pada gambaran 2 dimensi seperti yang biasa kita dapatkan pada radiograf periapikal, panoramik, maupun sefalometri. Kondisi klinis menuntut ketersediaan sistem multiplanar imaging yang mampu mencitrakan tubuh manusia secara detail dalam ukuran centimeter, bahkan dalam ukuran submillimeter. ${ }^{5}$ Sistem multiplanar imaging seperti computed tomography (CT) dan magnetic resonce imaging (MRI) mampu menggambarkan detail obyek dan mengatasi gambaran tumpang tindih (superimposisi) yang umumnya ditemukan pada pencitraan konvensional 2 dimensi. Meskipun penggunaan teknologi pencitraan terbaru seperti CT dan MRI memiliki sejumlah keunggulan yang tidak ditemukan pada radiografi 2 dimensi, namun penggunaan teknologi tersebut menimbulkan konsekuensi peningkatan biaya kesehatan bagi pasien. ${ }^{6}$ Selain itu, ketersediaan peralatan multiplanar imaging berteknologi tinggi saat ini masih terbatas pada kota-kota besar. ${ }^{7}$ Dengan demikian, sistem pencitraan konvensional 2 dimensi masih merupakan jenis pemeriksaan penunjang yang paling banyak dipergunakan, terutama di negara berkembang seperti Indonesia.

Orthopanthomography (OPG) atau radiografi panoramik merupakan teknik radiografi yang banyak dipergunakan untuk menentukan rencana perawatan dan diagnosa pada praktek dokter gigi. Radiograf panoramik menampilkan struktur fasial yang termasuk diantaranya adalah rahang atas, rahang bawah, dan persendian temporomandibular. Keseluruhan struktur anatomi tersebut ditampilkan pada satu citra tunggal. ${ }^{8}$ Radiograf panoramik didapatkan dengan melakukan paparan sinar $\mathrm{X}$ terhadap pasien, dimana sumber sinar $\mathbf{X}$ dan film (atau image receptor digital) bergerak dengan arah yang berlawanan dalam kecepatan yang sama mengelilingi kepala pasien. ${ }^{9}$

Radiograf panoramik banyak dimanfaatkan untuk screening pasien sebelum dilakukan perawatan protesa gigi, untuk memastikan ada tidaknya akar, kista, benda asing, dan neoplasma. ${ }^{6}$ Pengukuran arah horizontal pada radiograf panoramik dapat dilakukan pada rencana perawatan tumor, evaluasi kondisi tulang paska perawatan tumor dan fraktur rahang, serta evaluasi kondisi TMJ dan mandibula terkait dengan kecurigaan anomali perkembangan rahang (hiperplasi atau hipoplasi mandibula). Radiograf panoramik dapat dipergunakan untuk pemeriksaan radiografi secara luas pada area maksilomandibular, ${ }^{7}$ biaya pemeriksaannya rendah dan relatif terjangkau, serta teknik pencitraannya memerlukan paparan radiasi dengan dosis yang lebih rendah dibandingkan teknik pencitraan berteknologi tinggi seperti CT. ${ }^{10}$ Beberapa keunggulan tersebut menjadikan radiograf panoramik sebagai teknik radiograf ekstraoral yang paling banyak dipergunakan pada praktek kedokteran gigi, dan pemanfaatan radiograf panoramik pada praktek dokter gigi dari tahun ke tahun terus mengalami peningkatan. ${ }^{11,12}$

Namun demikian radiograf panoramik memiliki sejumlah keterbatasan karena gambaran yang dihasilkan mengalami perbesaran dan distorsi jika dibandingkan dengan ukuran yang sesungguhnya, sehingga diperlukan pengetahuan serta keahlian khusus untuk menghindarkan kesalahan informasi saat menginterpretasikan citra radiograf panoramik. ${ }^{7,13}$ Gambaran pada radiograf panoramik memiliki kontras dan detil yang rendah serta tidak mampu memberikan informasi dari sudut pandang cross sectional. Selain itu, pada radiograf panoramik seringkali didapatkan gambaran superimposisi (tumpang tindih) dari struktur anatomi lain (vertebra cervikalis, os hyoid, dan palatum durum) terhadap struktur maksila maupun mandibula. ${ }^{14}$

Radiografi panoramik telah dikenal oleh praktisi kedokteran gigi selama lebih dari setengah abad. ${ }^{15}$ OPG dipergunakan secara luas untuk screening, evaluasi penyakit periodontal, perencanaan 
perawatan orthodontik, bedah mulut, dan implan gigi. ${ }^{15}$ Prediksi dimensi tulang rahang merupakan faktor yang penting dalam diagnosa dan rencana perawatan implan gigi, impaksi, tumor, kista, dan temporomandibularjoint disorders (TMDs). Terlepas dari sejumlah kelemahannya, radiograf panoramik hingga saat ini masih banyak dimanfaatkan sebagai pemeriksaan penunjang oleh dokter gigi. Radiograf panoramik memiliki sejumlah kekurangan karena hanya mampu menampilkan hasil pencitraan dari struktur anatomi yang terletak pada focal through saja, sedangkan hasil pencitraan dari struktur anatomi yang terletak diluar focal trough akan tampak kabur atau mengalami distorsi. Selain itu, jaringan lunak dan struktur anatomi yang berupa ruangan yang terisi udara akan menyebabkan artefak radiolusen berupa air shadow pada radiograf panoramik, sehingga struktur jaringan keras yang bersuperimposisi dengan artefak tersebut tidak tercitrakan dengan baik. ${ }^{9}$ Senada dengan pendapat tersebut, Pittayapat et al. ${ }^{15}$ menyebutkan bahwa kelemahan teknik radiografi panoramik terutama berkaitan dengan distorsi geometris dan superimposisi struktur anatomi yang tercitrakan pada radiograf. Distorsi pada radiograf panoramik tergantung pada mesin sinar $X$ yang dipergunakan serta jenis pengukuran yang dilakukan. Besarnya distorsi berkisar antara 0,7-1,8 kali dibandingkan dengan ukuran sesungguhnya dari struktur anatomi yang dicitrakan. ${ }^{6,9}$

Proses pembentukan gambaran pada radiograf panoramik pada dasarnya menggunakan prinsip teknik tomografi sederhana dimana sumber sinar $\mathrm{X}$ dan film analog (atau image receptor pada radiografi digital) bergerak mengelilingi objek (dalam hal ini adalah kepala pasien). Pergerakan tomografik pada teknik panoramik dan jarak yang terbentang antara film dengan focal through mengakibatkan gambaran yang dihasilkan pada radiograf panoramik mengalami distorsi geometris dan perbesaran pada citra dihasilkan sekitar 1,3 kali lipat dibandingkan dengan ukuran struktur anatomi yang sesungguhnya. . $^{89}$ Distorsi atau perbesaran gambaran hasil pencitraan secara vertikal maupun horizontal pada radiograf panoramik sangat variatif, tergantung pada jenis mesin sinar $X$ yang dipergunakan untuk menghasilkan radiograf. ${ }^{5}$
Namun demikian, radiograf panoramik masih merupakan alternatif yang cukup bermanfaat dalam mencari informasi kondisi objek secara mesiodistal. Penelitian ini bertujuan untuk mengetahui perbedaan antara hasil pengukuran horizontal pada radiograf panoramik dibandingkan dengan hasil pengukuran sesungguhnya pada preparat mandibula. Hasil penelitian diharapkan dapat memberikan informasi terkait distorsi horizontal pada citra radiograf panoramik, khususnya pada fasilitas radiografi panoramik di RSGM Prof. Soedomo Fakultas Kedokteran Gigi Universitas Gadjah Mada. Hasil penelitian dapat dimanfaatkan oleh klinisi pada rencana perawatan tumor, evaluasi kondisi tulang paska perawatan tumor dan fraktur rahang, serta evaluasi kondisi TMJ dan mandibula terkait dengan kecurigaan anomali perkembangan rahang.

\section{METODE PENELITIAN}

Penelitian ini telah mendapatkan Keterangan Kelaikan Etik Penelitian (ethical clearance) dari Unit EtikadanAdvokasiFKGUGM. Penelitian dilaksanakan secara eksperimental dengan mencitrakan preparat tulang mandibula menggunakan mesin sinar $X$ ekstraoral panoramik. Sampel penelitian berupa 56 buah preparat tulang mandibula yang didapatkan dari Bagian Anatomi, Embriologi, dan Antropologi Fakultas Kedokteran UGM. Sampel yang dipergunakan dalam penelitian ini adalah preparat tulang rahang bawah (mandibula) manusia yang masih memiliki komponen prosesus kondilaris, prosesus koronoid, ramus, angulus, dan korpus mandibula secara utuh, dengan atau pun tanpa gigi geligi.

Sebelum dilakukan pengambilan data radiografi, setiap preparat diberi metal marker sejumlah 23 buah pada beberapa titik anatomis mandibula (Gambar 2). Metal marker yang digunakan pada penelitian ini berupa potongan lempeng tembaga $(\mathrm{Cu})$ tebal $0,4 \mathrm{~mm}$ berbentuk persegi dengan ukuran $2 \mathrm{~mm} x$ $2 \mathrm{~mm}$. Pemasangan metal marker ditujukan untuk memudahkan proses pengukuran dan memastikan bahwa pengukuran yang dilakukan pada radiograf panoramik digital dapat dilakukan pada titik acuan yang sama dengan pengukuran yang dilakukan pada preparat mandibula. 
Proses pembuatan radiograf panoramik dilakukan dengan memposisikan preparat tulang mandibula pada chin restdental X-rayunit menggunakan fiksator sedemikian rupa agar radiograf panoramik yang dihasilkan semirip mungkin dengan kondisi pasien terstandar yang memenuhi quality assurance radiografi. Pemeriksaan radiograf panoramik menggunakan dental $x$-ray Yoshida Panoura deluxe (Japan) dengan spesifikasi paparan 55-60kVp, $6 \mathrm{~mA}, 12$ detik dan menggunakan image receptor PSP (photostimulable phosphor plate). Image receptor PSP yang telah dipergunakan untuk mencitrakan tulang mandibula kemudian dipindai menggunakan Vista scan scanner. Selanjutnya proses ingradiograf dilakukan menggunakan komputer yang dilengkapi dengan software DBSWIN 4.5 dari Durr Dental. membagi mandibula menjadi 2 bagian yang sama besar pada sisi kanan dan kiri.

Pemeriksaan quality assurance radiografi dilakukan untuk memastikan bahwa radiograf yang dihasilkan memenuhi kualitas maksimal serupa dengan hasil pencitraan yang sesungguhnya pada pasien. Batasan yang dipergunakan dalam quality assurance radiografi panoramik pada penelitian ini adalah citra mandibula dengan dataran oklusal yang sedikit cekung, tidak tampak terbalik (cembung) ataupun mendatar, dan seluruh bagian tulang mandibula tampak pada radiograf.

Dari setiap preparat yang telah diberi metal marker dibuat sejumlah garis imajiner yang kemudian dipergunakan sebagai lokasi pengukuran. Pengukuran horizontal dilakukan pada 13 buah garis imajiner (selanjutnya disebut $\mathrm{H} 1$ sampai dengan $\mathrm{H} 8 \mathrm{~B}$, dapat

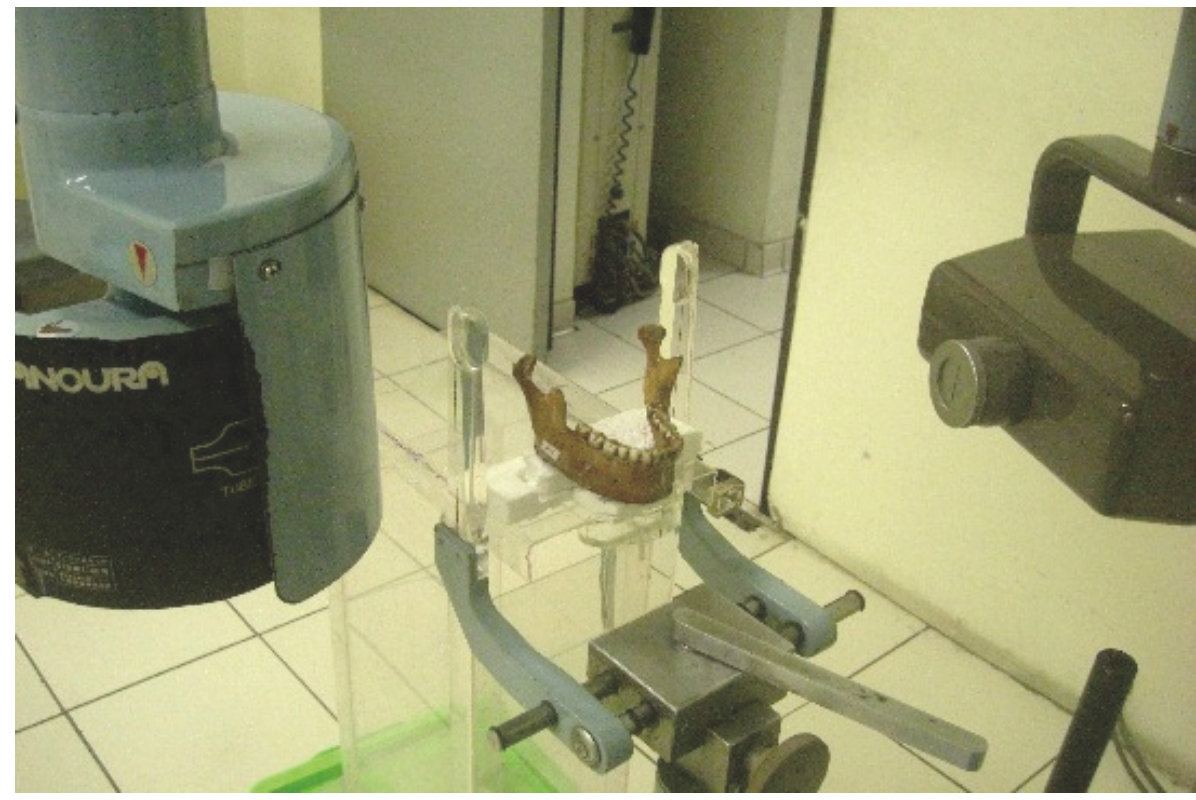

Gambar 1. Posisi Preparat Tulang Mandibula pada Pengambilan Radiograf Panoramik

Preparat tulang mandibula yang dipergunakan dalam penelitian diposisikan menggunakan fiksator sedemikian rupa agar radiograf panoramik yang dihasilkan semirip mungkin dengan kondisi pasien yang memenuhi quality assurance (penjaminan mutu) radiografi. Bagian mentum ditempatkan pada chin rest, sedangkan bagian gonion ditempatkan lebih tinggi daripada mentum agar ramus mandibula cenderung tegak lurus dengan bidang horizontal serta dataran oklusal membentuk sudut $20^{\circ}$ hingga $30^{\circ}$ di bawah garis horizontal. Midline mandibula ditempatkan di tengah chin rest dan secara imajiner disimak pada Gambar 2 dan Gambar 3). Pemilihan lokasi pengukuran horizontal pada penelitian ini dilakukan dengan mempertimbangkan area yang mewakili regio-regio rahang bawah yang kerap memerlukan pengukuran horizontal, antara lain regio gigi geligi dan korpus mandibula anterior (pengukuran $\mathrm{H} 6$ dan $\mathrm{H} 7$ ) dan posterior (pengukuran $\mathrm{H} 8$ ), regio ramus mandibula (pengukuran $\mathrm{H} 5$ ), regio caput prosesus kondilaris (pengukuran $\mathrm{H} 4$ ). Adapun pengukuran $\mathrm{H} 1, \mathrm{H} 2$, dan $\mathrm{H} 3$ ditujukan untuk mengetahui besaran distorsi citra pada pengukuran horizontal yang melintasi median line rahang bawah. 


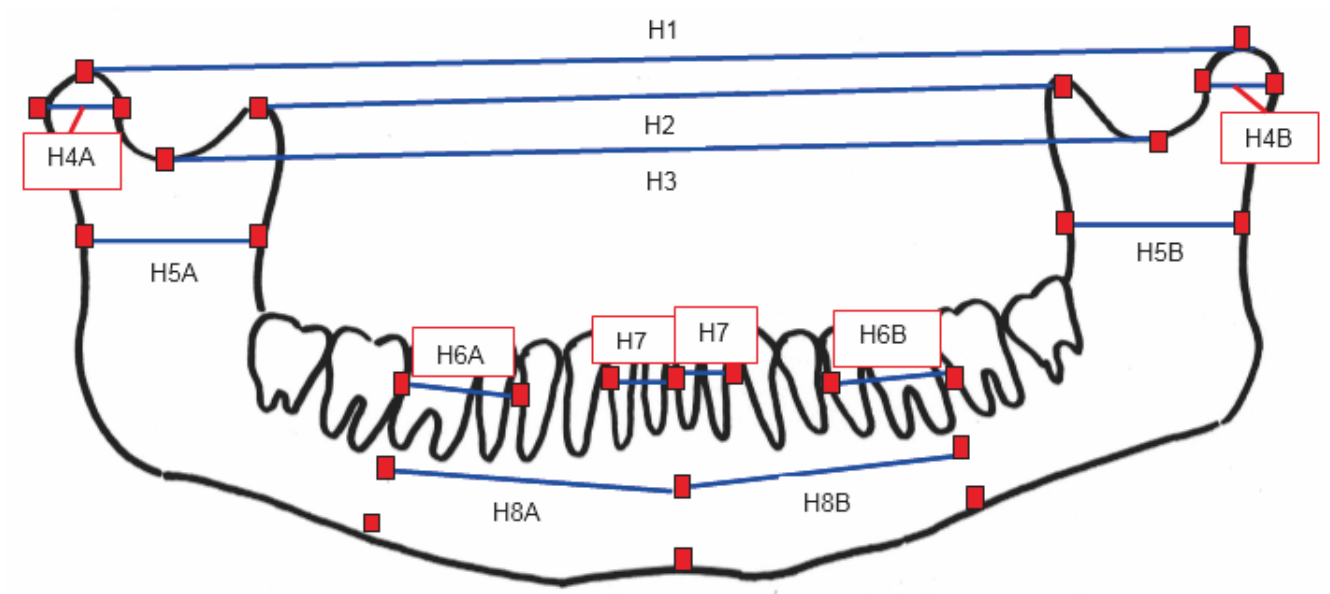

Gambar 2. Posisi Metal Marker dan Garis Imajiner Pengukuran Horizontal pada Preparat Tulang Mandibula (acuan pengukuran horizontal dimodifiksai dari penelitian Amir et al., 1998). ${ }^{6}$

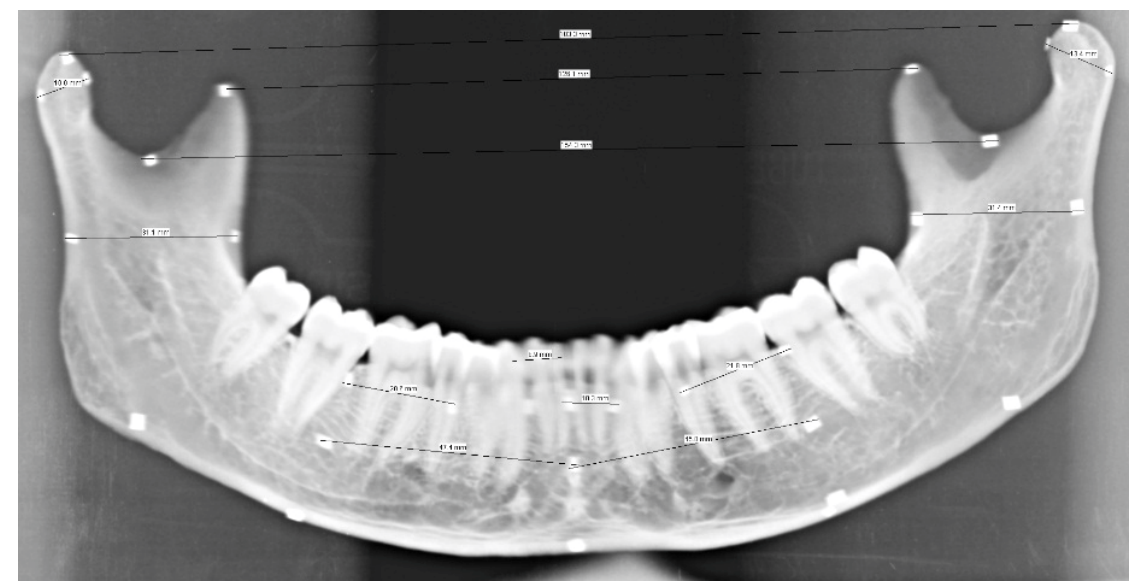

Gambar 3. Hasil Pengukuran Horizontal Mandibula (Menggunakan Komputer) pada Radiograf Panoramik Digital

Pengukuran horizontal pada preparat tulang menggunakan sliding caliper digital $\mathrm{Krisbow}^{\circledR}$ dengan ketelitian $0,01 \mathrm{~mm}$, sedangkan pengukuran pada radiograf panoramik dilakukan menggunakan komputer yang dilengkapi dengan software radiografi digital DBSWin4.5.

\section{HASIL PENELITIAN}

Untuk mengetahui konsistensi dan reliabilitas (kehandalan) pengukuran horizontal, dilakukan uji inter-rater reliability (IRR) menggunakan uji intraclass corelation (ICC) Cronbach's alpha. ${ }^{16,17}$ Untuk mengetahui reliabilitas intraobserver, pengukuran horizontal pada preparat mandibula dilakukan dua kali oleh satu orang pengamat dengan selang waktu 1 minggu. Sedangkan untuk mengetahui reliabilitas interobserver, pengukuran horizontal pada preparat mandibula dilakukan oleh dua orang pengamat. Hasil uji Cronbach's alpha intra-class correlation (ICC) pada penelitian ini ditampilkan pada Tabel 1.

Rangkuman hasil pengukuran, hasil uji beda (uji komparatif) Mann-Whitney dan rerata distorsi citra radiograf panoramik pada penelitian ini dapat disimak pada Tabel 2. 
Tabel 1. Hasil Uji Cronbach's Alpha Intra-Class Corelation (ICC) Pengukuran Horizontal

\begin{tabular}{lccccccccccccc}
\hline Reliabilitas & \multicolumn{11}{c}{ Jenis Pengukuran Horizontal } \\
\cline { 2 - 12 } Cronbach's alpha & H1 & H2 & H3 & H4A & H4B & H5A & H5B & H6A & H6B & H7A & H7B & H8A & H8B \\
Intra-observer & 0,99 & 0,99 & 0,99 & 0,99 & 0,98 & 0,99 & 0,99 & 0,98 & 0,91 & 0,98 & 0,91 & 0,99 & 0,99 \\
Inter-observer & 0,99 & 0,99 & 0,99 & 0,98 & 0,99 & 0,99 & 0,99 & 0,99 & 0,91 & 0,98 & 0,97 & 0,99 & 0,91 \\
\hline
\end{tabular}

Tabel 2. Rangkuman Data Hasil Pengukuran Horizontal, Hasil Uji Beda,dan Rerata Distorsi Radiograf Panoramik

\begin{tabular}{|c|c|c|c|c|c|c|c|c|c|c|c|}
\hline \multirow[t]{2}{*}{$\begin{array}{c}\text { Jenis } \\
\text { Pengukuran }\end{array}$} & \multicolumn{4}{|c|}{$\begin{array}{l}\text { Hasil Pengukuran pada } \\
\text { Preparat Mandibula (A) }\end{array}$} & \multicolumn{4}{|c|}{$\begin{array}{l}\text { Hasil pengukuran pada Radiograf } \\
\text { Panoramik (B) }\end{array}$} & \multirow[t]{2}{*}{$p$} & \multirow{2}{*}{$\begin{array}{c}\text { Rerata } \\
\text { distorsi } \\
\text { OPG } \\
(\mathrm{B} / \mathrm{A})\end{array}$} & \multirow{2}{*}{$\begin{array}{l}\text { Standar } \\
\text { Deviasi } \\
\text { Rerata } \\
\text { Distorsi }\end{array}$} \\
\hline & Rerata & SD & Minimal & Maksimal & Rerata & SD & Minimal & Maksimal & & & \\
\hline (1) & (2) & (3) & (4) & (5) & (6) & (7) & (8) & (9) & (10) & (11) & (12) \\
\hline $\mathrm{H} 1$ & 101,18 & 7,53 & 77,55 & 114,65 & 191,81 & 20,49 & 121,30 & 226,40 & $0,000^{*}$ & 1,91 & 0,26 \\
\hline $\mathrm{H} 2$ & 95,16 & 6,59 & 78,40 & 106,90 & 195,29 & 27,35 & 98,40 & 241,40 & $0,000^{*}$ & 1,37 & 0,31 \\
\hline $\mathrm{H} 3$ & 95,22 & 5,75 & 79,42 & 103,95 & 191,81 & 13,40 & 126,80 & 191,20 & $0,000^{*}$ & 1,64 & 0,14 \\
\hline $\mathrm{H} 4 \mathrm{~A}$ & 11,37 & 2,79 & 7,87 & 28,86 & 13,54 & 1,84 & 10,00 & 19,30 & $0,000^{*}$ & 1,22 & 0,15 \\
\hline $\mathrm{H} 4 \mathrm{~B}$ & 11,05 & 2,64 & 7,02 & 28,07 & 13,17 & 1,62 & 9,20 & 18,00 & $0,000^{*}$ & 1,22 & 0,14 \\
\hline H5A & 31,19 & 3,54 & 22,28 & 40,39 & 34,21 & 4,13 & 26,70 & 42,40 & $0,000^{*}$ & 1,10 & 0,08 \\
\hline H5B & 30,88 & 3,66 & 21,29 & 40,03 & 33,84 & 4,03 & 23,80 & 46,20 & $0,000^{*}$ & 1,10 & 0,10 \\
\hline $\mathrm{H} 6 \mathrm{~A}$ & 20,94 & 2,86 & 10,74 & 24,91 & 20,86 & 2,42 & 13,50 & 26,10 & 0,420 & 1,01 & 0,19 \\
\hline H6B & 20,31 & 3,34 & 10,11 & 25,31 & 19,88 & 2,49 & 12,80 & 25,70 & 0,123 & 1,00 & 0,22 \\
\hline $\mathrm{H} 7 \mathrm{~A}$ & 11,51 & 1,66 & 7,94 & 17,10 & 10,02 & 1,67 & 7,10 & 15,60 & $0,000^{*}$ & 0,87 & 0,06 \\
\hline H7B & 11,87 & 2,59 & 8,19 & 21,94 & 9,98 & 1,70 & 7,10 & 15,70 & $0,000^{*}$ & 0,85 & 0,10 \\
\hline $\mathrm{H} 8 \mathrm{~A}$ & 46,36 & 3,97 & 37,19 & 53,84 & 45,24 & 4,36 & 34,90 & 54,70 & 0,089 & 0,98 & 0,06 \\
\hline H8B & 46,51 & 3,60 & 36,65 & 141,08 & 43,11 & 5,16 & 32,10 & 51,80 & 0,081 & 0,95 & 0,11 \\
\hline
\end{tabular}

Keterangan: * terdapat perbedaan rerata yang bermakna $(p<0,05)$

\section{PEMBAHASAN}

Pada Tabel 1 dapat diamati bahwa reliabilitas intraobserver dan interobserver pengukuran horizontal pada penelitian ini seluruhnya menunjukkan nilai diatas 0,9. Hasil uji Cronbach's Alpha Intra-Class Corelation (ICC) dengan nilai 1 menunjukkan perfect agreement, nilai 0 menunjukkan random agreement, sedangkan nilai minus menunjukkan systematic disagreement. ${ }^{17}$ Selanjutnya nilai ICC kurang dari 0,40 menunjukkan poor agreement, nilai 0,40-0,59 menunjukkan fair agreement, nilai 0,60-0,74 menunjukkan good agreement, sedangkan nilai 0,75-1,0 menunjukkan excellent agreement. ${ }^{17}$ Berdasarkan sistem peringkat tersebut, maka reliabilitas pengukuran horizontal dalam penelitian ini menunjukkan excellent agreement, baik pada uji reliabilitas intraobserver maupun uji reliabilitas interobserver.
Dari hasil uji Mann-Whitney pada kolom (10) Tabel 2, dapat diamati bahwa terdapat perbedaan rerata yang bermakna $(p<0,05)$ pada hasil pengukuran horizontal, kecuali pada pengukuran H6A, H6B, H8A, dan H8B. Pada Gambar 1 dapat diamati bahwa pengukuran H6Adan H6B merupakan pengukuran horizontal yang dilakukan pada regio posterior mandibula, dari interdental gigi 4 dan 5 hingga interdental gigi 6 dan 7 rahang bawah. Sedangkan pengukuran H8A dan H8B merupakan pengukuran dari regio anterior (median line) corpus mandibula hingga regio posterior (sekitar distoapikal gigi 6 rahang bawah).

Pada kolom (11) Tabel 2 dapat diamati bahwa pengukuran yang dilakukan pada regio posterior dan area corpus mandibula yang tercitrakan pada radiograf panoramik memiliki distorsi yang minimal. 
Nilai distorsi OPG pada penelitian ini didapatkan dengan cara membagi hasil pengukuran pada radiograf panoramik dengan hasil pengukuran pada preparat mandibula sebagai kontrol penelitian. Adapun rerata nilai distorsi OPG yang paling kecil pada penelitian adalah sebesar 1,00-1,01 kali pada hasil pengukuran $\mathrm{H} 6 \mathrm{~A}$ dan $\mathrm{H} 6 \mathrm{~B}$. Hal tersebut memberikan informasi bahwa pada penempatan posisi objek (dalam penelitian ini berupa preparat mandibula) yang tepat pada pengambilan radiograf panoramik, gambaran regio posterior mandibula dan corpus mandibula hampir tidak mengalami distorsi geometris sama sekali, atau dengan kata lain distorsi geometris pada area tersebut sangat rendah dengan perbesaran/pengecilan gambaran mendekati nilai 1 (ukuran pada radiograf panoramik di area tersebut sangat mendekati ukuran pada obyek yang sesungguhnya, yaitu tulang mandibula).

Hasil pengukuran horizontal pada regio anterior mandibula (H7A dan H7B) dan pengukuran horizontal yang memanjang dari regio kiri hingga kanan dengan melintasi median line pada radiograf panoramik menunjukkan perbedaan rerata yang bermakna $(p<0,05)$ dibandingkan dengan hasil pengukuran pada preparat mandibula (kontrol). Pada kolom (11) Tabel 2 dapat diamati bahwa nilai distorsi pada regio anterior mandibula berdasarkan pengukuran $\mathrm{H} 7 \mathrm{~A}$ dan $\mathrm{H7B}$ dalam penelitian ini adalah 0,85-0,87 kali dibandingkan ukuran yang sesungguhnya pada preparat mandibula. Dengan demikian maka hasil pengukuran horizontal pada regio anterior mandibula (H7A dan H7B) cenderung mengalami pengecilan citra sebesar 13\%-15\% dibandingkan dengan ukuran objek yang sesungguhnya.

Adapun nilai distorsi OPG yang terbesar pada hasil pengukuran horizontal didapatkan pada pengukuran $\mathrm{H} 1$ sebesar 1,91 kali lipat dibandingkan kontrol, dilanjutkan dengan pengukuran $\mathrm{H} 3$ (dengan distorsi sebesar 1,64 kali) dan $\mathrm{H} 2$ (dengan distorsi sebesar 1,37kali). Hasil tersebut menunjukkan bahwa pengukuran horizontal pada radiograf panoramik yang dilakukan secara bilateral dengan melintasi median line cenderung kurang akurat dan mengalami distorsi cukup besar (37\%-91\%). Hasil penelitian ini sesuai dengan penelitian sebelumnya yang menyebutkan bahwa pengukuran satu sisi pada radiograf panoramik memiliki keakuratan lebih baik (hampir mendekati ukuran yang sesungguhnya), sedangkan pengukuran horizontal yang melintasi median line memiliki distorsi terbesar, sehingga pengukuran tersebut sebaiknya tidak dilakukan pada saat penegakkan diagnosa menggunakan radiograf panoramik. ${ }^{6}$

Salah satu informasi cukup penting yang didapatkan pada penelitian ini antara lain bahwa hasil pengukuran yang dilakukan pada regio ramus (H5A dan H5B) dan caput kondilus mandibula (H4A dan $\mathrm{H} 4 \mathrm{~B}$ ) yang tergambar pada OPG memiliki perbedaan yang bermakna $(p<0,05)$ dibandingkan dengan hasil pengukuran yang sesungguhnya pada obyek (preparat mandibula). Nilai distorsi OPG yang didapatkan pada penelitian ini masingmasing adalah 1,22 kali lipat untuk pengukuran lebar antero posterior caput kondilus kanan maupun kiri (H4A dan H4B) dan 1,10 kali lipat untuk pengukuran lebar antero posterior ramus mandibula kanan maupun kiri (H5A dan H5B). Pengukuran lebar antero posterior serta pengamatan terhadap bentuk caput condylus selama ini dipergunakan dalam menunjang diagnosa pada kasus-kasus kelainan temporomandibular joint (TMJ). Hasil pengukuran horizontal pada penelitian ini menunjukkan kesesuaian dengan penelitian sebelumnya ${ }^{18}$ yang menyebutkan bahwa distorsi OPG berkisar $20 \%$, yang berarti bahwa perbesaran gambaran OPG sekitar 1,2 kali lipat dibandingkan dengan ukuran obyek yang dicitrakan. Penelitian sebelumnya menyebutkan bahwa besaran distorsi radiograf panoramik dapat berbeda-beda pada setiap mesin, ${ }^{6}$ sehingga jika penelitian yang serupa dengan penelitian ini dilaksanakan dengan menggunakan dental panoramic $X$-ray jenis lain, maka hasil penelitian yang akan didapatkan pada penelitian tersebut tidak akan sama dengan hasil yang didapatkan pada penelitian ini.

\section{KESIMPULAN}

Dari hasil yang didapatkan pada penelitian ini, dapat ditarik kesimpulan bahwa terdapat perbedaan rerata yang bermakna $(p<0,05)$ antara hasil pengukuran pada radiograf panoramik dibandingkan dengan hasil pengukuran yang sesungguhnya pada preparat mandibula, kecuali pada hasil pengukuran horizontal regio gigi geligi 
posterior dan regio median line hingga posterior pada korpus mandibula. Pengukuran horizontal pada radiograf panoramik memiliki akurasi yang baik jika dilakukan pada regio posterior, namun cenderung tidak akurat jika dilakukan secara memanjang melintasi median line.

Penelitian lebih lanjut diperlukan untuk mengetahui besaran distorsi pengukuran vertikal dan oblique pada radiograf panoramik. Selain itu, perlu dipertimbangkan penggunaan metal marker dengan bentuk membulat dan fiksasi metal marker menggunakan material yang lebih baik, untuk mencegah bias pada hasil penelitian berikutnya.

\section{DAFTAR PUSTAKA}

1. Gkoumas S, Wang Z, Abis M, Arboleda C, Tudosie G, Donath T, Brönnimann C, SchulzeBriese C, Stampanoni M. Grating-based interferometry and hybrid photon counting detectors: Towards a new era in X-ray medical imaging. Nucl Instrum Methods. 2015, http:// dx.doi.org/10.1016/j.nima.2015.08.017i

2. Sher-Lin C. A note on digital dental radiography in forensic odontology. J Forensic Dent Sci. 2014; 6(3): 197-201.

3. Priminiarti M, Kiswanjaya B, Iskandar HB. Radiographic Evaluation of Osteopororsis through detection of jaw bone changes: a simplified early osteoporosis detection effort. Makara Kesehatan. 2010; 14(2): 51-6.

4. Ludlow JB and Mol A. Digital Imaging. dalam Oral Radiologi Principles and Interpretations. 7th ed. Toronto: Mosby; 2014. H.41.

5. Gahleitner A, Watzek G, Imhof H. Dental CT: imaging technique, anatomy, and pathologic conditions of the jaws. Eur Radiol. 2003; 13:366-76.

6. Amir C, Asja C, Melita VP, Adnan C, Vjekoslav $\mathrm{J}$, Muretic I. Evaluation of the precision of dimensional measurement of the mandible on panoramic radiographs. Oral Surg Oral Med Oral Pathol Oral Radiol Endod.1998; 86: 242-8.

7. Langlois CdO, Sampaio MCC, Silvia AER, da Costa NP, Rockenbach MIB. Accuracy of liniar measurement before and after digitizing periapikal and panoramic radiography images. Braz Dent J. 2011; 22(5): 404-9.

8. Mallya SM and Lurie AG. Panoramic Imaging. dalam Oral Radiology Principles and Interpretations. 7th ed. Toronto: Mosby; 2014. H.166.

9. Whaites E and Drage N. Essentials of Dental Radiography and Radiology. $5^{\text {th }}$ ed. Churchill Livingstone Elsevier; 2013. H.175-176.

10. Nishikawa K, Suehiro A, Sekine H, Kousuge $Y$, Wakoh M, Sano $T$. Is linear distance measuredby panoramic radiography reliable? Oral Radiol. 2010; 26:16-9.

11. Ong RGK, Stevenson MR. Evaluation of bone density in the mandibles of young Australian adult of Mongoloid and Caucasoid descent. Dentomaxillofac Radiol. 1999; 28:20-5.

12. TaguchiA. Panoramic radiographs for identifying individuals with undetected osteoporosis. Jpn Dent Sci Rev. 2009; 45:109-20.

13. Watanabe PCA, Farmer A, Watanabe MGC, Issa JPM. Radiographic signal detection of systemic disease: Orthopantomographic radiography. Int J Morphol. 2008; 26(4): 915-26.

14. Park T, Choi H. Implant Radiology in Dental Practice. Oral Radiol. 2001; 17:1

15. Pittayapat P, Galiti D, Huang Y, Dreesen K, Scheurs M, Couto Sauza P, Rubira-Bullen IRF, Westphalen FH, Pauwels R, Kalema G, Willems $G$, Jacobs $R$. An in vitro comparison of subjective image quality of panoramic views acquired via $2 \mathrm{D}$ or $3 \mathrm{D}$ imaging. Clin Oral Invest. Verlag: Springer; 2012.

16. Murti, B. 2011. Validitas dan Reabilitas Pengukuran. Matrikulasi Program Studi Doktoral, Fakultas Kedokteran, UNS.

17. Hallgren KA. Computing Inter-Rater Reability for Observational Data: An Overview and Tutorial. Tutor Quant Meth for Psych. 2012; 8(1): 23-34.

18. Farman AG. Panoramic Radiology, Seminars on Maxillofacial Imaging and Interpretation. New York: Springer; 2007. 